\title{
AN ANALYSIS OF THE STUDENTS' WRITING ERROR IN REPORT TEXT
}

\author{
BY: \\ MEIKARDO SAMUEL PRAYUDA \\ (UNIVERSITAS KATOLIK SANTO THOMAS MEDAN)
}

\begin{abstract}
This research purposed to measure the students'writing errors in report text so that it can find the kinds of errors that faced by the students in the writing of report text. The subject of this research were the students of grade $\mathrm{X}$ at SMA Negeri 1 Sei. Balai in academic year of 2015/2016. The population of the research were 105 students in three classes while the sample were 27 students. This research was conducted in descriptive research and the method in taking the sample was random sampling. The instruments for this researchwere observation and interview. The result of this study was that most students did errors in the word form. 11 students did errors in their construction in word form in writing report text and then followed by the errors in word choice. 10 students did errors in their word choice. Next, followed by error in punctuation. 9 students did error in the punctuation. It is suggested in teaching writing especially in writing report text, the teacher should put a serious intention in the part of word choice, word form, and also punctuation since these instruments are the most troublesome parts in this study of the students' writing error.
\end{abstract}

Keywords: an analysis, writing error, report text.

\section{INTRODUCTION}

Language is important in developing intelectual, social, and emotional of people. Moreover, by language, we can do communication to others. By considering how important language in social relation, government had determined some foreign languages to be taught in the formal school. One of them is English. English has four main skills including listening, speaking, reading, and writing. To be good in English, students need to master all of the four main skills. However, writing was believed as the hardest one to learn. Unlike the other skills, writing was unique. It provided an outcome from the process.

The process of writing itself is unique and sometimes hard for the students in Indonesia since they learn English not as their mother language. To be able to follow the process, the students need to understand about the grammatical pattern of what they wanted to write. The grammatical pattern in writing is 
different according to the purpose of the writing. The purpose in writing determines what kind of text to write. In this case, we know genre as the types of text. The types of text in English divide into some parts including procedure, descriptive, recount, narrative, news item, analytical exposition, hartatory, spoof, explanation, and report. All of the types of text above are mentioned in curriculum as the objective in writing.

The objective of the curriculum in writing is the ability of the students to understand and to create various short functional text and monologue including essay in the form of procedure, descriptive, recount, narrative, report, news item, analyticalexposition, hortatoryexposition, spoof, explanation, discussion, review, and publicspeaking". It was hoped that by creating the objective of the curriculum as explained above, the teachers of the English language subject in Indonesia would be able to lead their students to achieve the objective. However, the objective of the curriculum above seems to be failed to achieve. It can be seen from the writing product of the students. As an example in the writing report text, the researcher asked a student to make a report text, however, the students were confused in constructing the text based on the generic structure of the text and the result was the text did not follow the generic structure of the report text. As we knew, the aim of the report text was to describe the way things are, with reference to a range of natural, man made and social phenomena in our environment. When the students failed in constructing the text based on the structure of the text, the students also failed to achieve the aim of the report text. In other case, the students also failed in constructing the verb agreement in the text related to the tenses used in the report text. It could be seen from the test that the researcher gave to a student. The researcher asked the student to translate a sentence from Indonesia into English. The test was: "Dia perempuan pergi ke sekolah setiap hari." The student's answer was: "She go to school everyday." From the student's answer we could see that the student's failed in constructing the suitable verb agreement as from the verb "go" need to add "es" for the subject "she". More errors also found in the use of articles. As when the researcher asked the student to translate the sentence: "Saya memiliki seekor gajah." The student's answer 
was: "I have a elephant." The students failed to use the appropriate article in their writing. It could be seen from the use of article "a" was not appropiate for the noun "elephant" which started with the vowel sound. Not only that, some students also did errors in the use of punctuation. Like the use of full stop at the end of the sentence. Sometimes the students forgot to put the full stop at the end of the sentence as the sentence: "I have two books".

Therefore, in order to fix the students errors in writing, this research wanted to do an analysis of the students' writing errors in report text at X grade students of SMA Negeri 1 Sei Balai in academic year of 2015/2016. By completing this research, it was hoped that the students would understand what kinds of errors they did and able to fix the errors. As for the teachers, the completing of this research would be able to help them in constructing the suitable strategy and media to overcome the errors made by the students in writing, especially in writing report text.

\section{RESULT}

This research was purposed to find out the students' writing errors in report text at $\mathrm{X}$ grade students of SMA Negeri 1 Sei Balai in academic year of 2015/2016. The data collection about the students' errors in writing the report text that had been gathered by the writer will be presented in the tables bellow.

\section{Subject-verb agreement error}

Subject-verb agreement error is error that occur when a subject does not match the following verb. From the analysis, the writer found that from 27 samples, there are 4 students who make error in the construction of subject-verb agreement.

Table 4.1.1 Subject-verb agreement error

\begin{tabular}{|c|c|c|}
\hline $\begin{array}{l}\text { Students Initial } \\
\text { Name }\end{array}$ & Error Found & Description \\
\hline A & Rabbit are colours. & $\begin{array}{l}\text { Rabbit is a singular subject which means } \\
\text { that it is an error if the singular subject } \\
\text { followed by helping verb are. }\end{array}$ \\
\hline $\mathrm{B}$ & Handphone have a variety. & Handphone is a singular subject which \\
\hline
\end{tabular}




\begin{tabular}{lll}
\hline & $\begin{array}{l}\text { means that it is an error if the singular } \\
\text { subject followed by helping verb have. }\end{array}$ \\
\hline C & $\begin{array}{ll}\text { Kangaroos is know to have a } \\
\text { strong front leg muscle. }\end{array}$ & $\begin{array}{l}\text { Kangaroos is a plural subject which } \\
\text { means that it is an error if the plural } \\
\text { subject followed by helping verb is. }\end{array}$ \\
\hline D & Some cat are long tail. & $\begin{array}{l}\text { Some is a plural but the subject, cat, does } \\
\text { not add with - }\end{array}$ \\
\hline Total students' errors in subject-verb agreement & $\mathbf{4}$ Students \\
= &
\end{tabular}

\section{Verb tense error}

Verb tense error is error that occur when a verb does not follow the rules of what tense suit the text. From the analysis, the writer found that from 27 samples, there are 2 students who make errors in the construction of verb tense.

Table 4.1.2 Verb tense error

\begin{tabular}{lll}
$\begin{array}{l}\text { Students } \\
\text { Name }\end{array}$ & Initial & Description \\
\hline $\mathrm{V}$ & $\begin{array}{ll}\text { Placental animal were better } \\
\text { able to compete for food. }\end{array}$ & $\begin{array}{l}\text { Report text is using present tense. The } \\
\text { existance of the helping verb were shows } \\
\text { that the writer has made an error in the } \\
\end{array}$ \\
& $\begin{array}{ll}\text { Tabuik was carried by } \\
\text { people. }\end{array}$ & $\begin{array}{l}\text { Report text is using present tense. The } \\
\text { existance of the helping verb was shows } \\
\text { that the writer has made an error in the }\end{array}$ \\
& \begin{tabular}{l} 
verb tense. \\
\hline Total students' errors in verb tense $=$
\end{tabular}
\end{tabular}

\section{Verb form error}

Verb form error is error that occur when the form of a verb does not follow structure of the sentence in the text. From the analysis, the writer found that from 27 samples, there is 1 student who make error in the construction of verb form.

Table 4.1.3 Verb form error

\begin{tabular}{llll}
\hline $\begin{array}{l}\text { Students } \\
\text { Name }\end{array}$ & Initial & Error Found & Description \\
\hline
\end{tabular}




\begin{tabular}{|c|c|c|}
\hline $\mathrm{C}$ & $\begin{array}{l}\text { Kangaroos is know to have a } \\
\text { strong front leg muscle. }\end{array}$ & $\begin{array}{l}\text { The form of the sentence is in passive } \\
\text { form, therefore the verb know need to be } \\
\text { changed into known. }\end{array}$ \\
\hline & $s$ in verb form $=$ & 1 Student \\
\hline
\end{tabular}

\section{Singular/plural ending error}

Singular/plural ending error is error that occur when the form of a noun does not follow the rules in making a noun become a singular or plural by $-\mathrm{s}$, or es. From the analysis, the writer found that from 27 samples, there are 4 students who make error in the construction of singular/plural ending

Table 4.1.4 Singular/plural ending error

\begin{tabular}{|c|c|c|}
\hline $\begin{array}{l}\text { Students Initial } \\
\text { Name }\end{array}$ & Error Found & Description \\
\hline $\mathrm{D}$ & $\begin{array}{l}\text { Some cat are long tail and } \\
\text { some other are short tail. }\end{array}$ & $\begin{array}{l}\text { The noun cat, need to add }-\mathrm{s} \text { because the } \\
\text { word some has shown that the noun is } \\
\text { plural. }\end{array}$ \\
\hline $\mathrm{N}$ & To have six string to differ. & $\begin{array}{l}\text { The noun string, need to add }-\mathrm{s} \text { because } \\
\text { the word six has shown that the noun is } \\
\text { plural. }\end{array}$ \\
\hline $\mathrm{R}$ & $\begin{array}{l}\text { Cat is a animals which many } \\
\text { take care people. }\end{array}$ & $\begin{array}{l}\text { The noun animals, does not need to add - } \\
\mathrm{s} \text { because the subject is introduced by } \\
\text { article a which means that it is singular. }\end{array}$ \\
\hline $\mathrm{W}$ & $\begin{array}{l}\text { An elephant is the largest and } \\
\text { strongest animals which live } \\
\text { in land. }\end{array}$ & $\begin{array}{l}\text { The noun animals, does not need to add - } \\
\mathrm{s} \text { because the subject is introduced by } \\
\text { article an which means that it is singular. }\end{array}$ \\
\hline Total students' er & rs in singular/plural ending $=$ & 4 Students \\
\hline
\end{tabular}

\section{Word form error}

Word form error is error that occur when the form of a word does not follow structure of the correct word form in english. From the analysis, the writer found that from 27 samples, there are 14 students who make error in the construction of word form.

Table 4.1.5 Word form error 


\begin{tabular}{llll}
\hline $\begin{array}{l}\text { Students } \\
\text { Name }\end{array}$ & Initial & Error Found & Description \\
\hline A & Handphond serves & to & Correction need to be made in the \\
& $\begin{array}{l}\text { communicate indirectly } \\
\text { the crowd. }\end{array}$ & & $\begin{array}{l}\text { to } \\
\text { writing of handphond. It should be } \\
\text { handphone. }\end{array}$
\end{tabular}

\begin{tabular}{ll}
\hline B It haves long ear. & Correction need to be made in the \\
writing of haves. It should be has.
\end{tabular}

\begin{tabular}{|c|c|c|}
\hline $\mathrm{C}$ & $\begin{array}{l}\text { Ow are colors white and } \\
\text { black. }\end{array}$ & $\begin{array}{l}\text { Correction need to be made in the } \\
\text { writing of ow. It should be cow. }\end{array}$ \\
\hline $\mathrm{E}$ & $\begin{array}{l}\text { Kuta beach is also inhabitant } \\
\text { of green turtes. }\end{array}$ & $\begin{array}{l}\text { Correction need to be made in the } \\
\text { writing of turtes. It should be turtles. }\end{array}$ \\
\hline G & $\begin{array}{l}\text { Football or soccer, which is } \\
\text { considered to be the most } \\
\text { populer sport in the word is } \\
\text { a team sport played between } \\
\text { two teams of eleven playes } \\
\text { using a spherical ball. }\end{array}$ & $\begin{array}{l}\text { Correction need to be made in the } \\
\text { writing of populer, word, and playes. } \\
\text { It should be popular, world, and } \\
\text { players. }\end{array}$ \\
\hline I & Moon is satelite eart. & $\begin{array}{l}\text { Correction need to be made in the } \\
\text { writing of eart. It should be earth. }\end{array}$ \\
\hline $\mathrm{J}$ & $\begin{array}{l}\text { Book's are for reading and } \\
\text { writing. }\end{array}$ & $\begin{array}{l}\text { Correction need to be made in the } \\
\text { writing of book's. It should be books. }\end{array}$ \\
\hline $\mathrm{M}$ & $\begin{array}{l}\text { They are played by bands in } \\
\text { dence halls, caffee, } \\
\text { restaurants, night clubs, } \\
\text { andon television. }\end{array}$ & $\begin{array}{l}\text { Correction need to be made in the } \\
\text { writing of andon. It should be and on. }\end{array}$ \\
\hline $\mathrm{P}$ & $\begin{array}{l}\text { They breathe air but they } \\
\text { cannot survive on land. }\end{array}$ & $\begin{array}{l}\text { Correction need to be made in the } \\
\text { writing of cannot. It should be can not. }\end{array}$ \\
\hline $\mathrm{Q}$ & $\begin{array}{l}\text { The upper platform features } \\
\text { steventy two small stupas } \\
\text { surrounding one large } \\
\text { central stupa. }\end{array}$ & $\begin{array}{l}\text { Correction need to be made in the } \\
\text { writing of steventy. It should be } \\
\text { seventy. }\end{array}$ \\
\hline$S$ & $\begin{array}{l}\text { Elephent is the largest and } \\
\text { strongest of all animals. }\end{array}$ & $\begin{array}{l}\text { Correction need to be made in the } \\
\text { writing of elephent. It should be }\end{array}$ \\
\hline
\end{tabular}




\begin{tabular}{lll}
\hline U & elephant. \\
& $\begin{array}{l}\text { There are many people } \\
\text { onvolved in the bunying and } \\
\text { selling activity. }\end{array}$ & $\begin{array}{l}\text { Correction need to be made in the } \\
\text { writing of onvolved and bunying. It } \\
\text { should be involved and buying. }\end{array}$ \\
\hline $\mathrm{X}$ & $\begin{array}{l}\text { Camel can travel in long } \\
\text { distan ces without food and } \\
\text { drink at all. }\end{array}$ & $\begin{array}{l}\text { Correction need to be made in the } \\
\text { writing of distan and ces. It should be } \\
\text { distances. }\end{array}$ \\
\hline M & $\begin{array}{l}\text { Correction need to be made in the } \\
\text { her tradisional activities. }\end{array}$ & should be other and traditional. \\
\hline
\end{tabular}

\section{Word choice error}

Word choice error is error that occur when a word does not fit the context of the sentence in a text. From the analysis, the writer found that from 27 samples, there are 10 students who make error in the construction of word choice.

Table 4.1.6 Word choice error

\begin{tabular}{|c|c|c|c|}
\hline $\begin{array}{l}\text { Students } \\
\text { Name }\end{array}$ & Initial & Error Found & Description \\
\hline B & & Rabbit likes very all people. & $\begin{array}{l}\text { The word very is not } \\
\text { necessary. }\end{array}$ \\
\hline $\mathrm{F}$ & & $\begin{array}{l}\text { They are very beautiful and and varied } \\
\text { in color. }\end{array}$ & $\begin{array}{l}\text { The word and is not } \\
\text { necessary to repeat. }\end{array}$ \\
\hline G & & $\begin{array}{l}\text { The winners are those who score the } \\
\text { most goals. }\end{array}$ & $\begin{array}{l}\text { The word most is not } \\
\text { appropiate with the context. } \\
\text { It is better to put more. }\end{array}$ \\
\hline $\mathrm{H}$ & & Bag is thing to save and take matter. & $\begin{array}{l}\text { The word matter is not } \\
\text { appropiate with the context. } \\
\text { It is better to put many } \\
\text { things. }\end{array}$ \\
\hline I & & There are not gravitation. & $\begin{array}{l}\text { The word not is not } \\
\text { appropiate with the context. } \\
\text { It is better to put no. }\end{array}$ \\
\hline $\mathrm{K}$ & & $\begin{array}{l}\text { Bluse is clothes are to be used in } \\
\text { everyday situations. }\end{array}$ & $\begin{array}{l}\text { The word are is not } \\
\text { necessary }\end{array}$ \\
\hline
\end{tabular}




\begin{tabular}{lll}
\hline $\mathrm{M}$ & $\begin{array}{l}\text { The songs are mainly simple must } \\
\text { with lyrics about love. }\end{array}$ & $\begin{array}{l}\text { The word must is not } \\
\text { necessary }\end{array}$ \\
\hline $\mathrm{N}$ & Guitar is luck to play music. & The word luck is not \\
& appropiate with the context. \\
& It is better to put good. \\
\hline $\mathrm{O}$ & The grow especially. & Incomplete sentence. \\
\hline $\mathrm{R}$ & The feather is smooth. & The word feather is not \\
& $\begin{array}{l}\text { appropiate with the context. } \\
\text { It is better to put hairy. }\end{array}$
\end{tabular}

\section{Article error}

Article error is error that occur when an article does not fit the context or the rules in using the article. From the analysis, the writer found that from 27 samples, there are 4 students who make error in the construction of word choice. Table 4.1.7 Article error

\begin{tabular}{lll}
$\begin{array}{l}\text { Students } \\
\text { Name }\end{array}$ & Initial & Description \\
\hline $\mathrm{D}$ & Cat is a animal. & $\begin{array}{l}\text { Article a is not suitable with the noun. It } \\
\text { should be an. }\end{array}$ \\
\hline $\mathrm{F}$ & The have more than 100 & $\begin{array}{l}\text { Article the is not necessary to put before } \\
\text { the verb have. }\end{array}$ \\
\hline $\mathrm{M}$ & Thecies in nature. & Article the is not necessary to put before \\
& & the verb are. \\
\hline $\mathrm{R}$ & Cat is a animal. & Article a is not suitable with the noun. It \\
& should be an. \\
\hline Total students' errors in article $=$ & $\mathbf{4}$ Students \\
\hline
\end{tabular}

\section{Preposition error}

Preposition error is error that occur when a prepositon does not appear by following the rules in using the preposition. From the analysis, the writer found that from 27 samples, there is 1 student who make error in the construction of preposition.

Table 4.1.8 Preposition error 


\begin{tabular}{lll}
\hline $\begin{array}{l}\text { Students } \\
\text { Name }\end{array}$ & Initial & Error Found \\
\hline $\mathrm{Z}$ & $\begin{array}{l}\text { On tabuik was carried by } 40 \\
\text { people. }\end{array}$ & $\begin{array}{l}\text { It is not necessary to put the preposition } \\
\text { on infront of the word tabuik. }\end{array}$ \\
\hline Total students' errors in preposition $=$ & 1 Student \\
\hline
\end{tabular}

\section{Phrasal verb error}

Phrasal verb error is error that occur when a group of verb that act as phrase does not appear by following the rules in using the phrasal verb. From the analysis, the writer found that from 27 samples, there is 1 student who make error in the construction of phrasal verb.

Table 4.1.9 Phrasal verb error

\begin{tabular}{lll}
\hline Students Initial Name & Error Found & Description \\
\hline $\mathrm{C}$ & Kangaroos is know to have a & The phrasal verb is know \\
& strong front leg. & found error in the form of the \\
& verb know. It should be is \\
& known. \\
\hline Total students' errors in phrasal verb $=$ & $\mathbf{1}$ Student \\
\hline
\end{tabular}

\section{Punctuation error}

Punctuation error is error that occur when a construction of sentence that need to add punctuation does not follow the rules in using the punctuation. From the analysis, the writer found that from 27 samples, there are 9 students who make error in the construction of punctuation.

Table 4.1.10 Punctuation error

\begin{tabular}{lll}
\hline Students Initial Name & Error Found & Description \\
\hline A & $\begin{array}{l}\text { Handphond have a variety of } \\
\text { sizes, shapes and prices. }\end{array}$ & $\begin{array}{l}\text { After shapes and before and need } \\
\text { to add a comma. }\end{array}$ \\
\hline F & Such as white, pink, yellow and & After yellow and before and need \\
& blue. & to add a comma. \\
\hline H & Bag is a thing to save and take & At the end of sentence need to add \\
& matter & full stop. \\
\hline I & Moon do not shine generally & At the end of sentence need to add \\
& & full stop. \\
\hline
\end{tabular}




\begin{tabular}{|c|c|c|}
\hline $\mathrm{J}$ & $\begin{array}{l}\text { Book's are for reading and } \\
\text { writing }\end{array}$ & $\begin{array}{l}\text { At the end of sentence need to add } \\
\text { full stop. }\end{array}$ \\
\hline $\mathrm{T}$ & $\begin{array}{l}\text { Cow has many colors as white } \\
\text { color. Black color. Brown color. }\end{array}$ & $\begin{array}{l}\text { The three sentences need to unite } \\
\text { by replacing the full stop and put } \\
\text { comma. }\end{array}$ \\
\hline $\mathrm{U}$ & $\begin{array}{l}\text { All over the world, people live } \\
\text { by buying and selling }\end{array}$ & $\begin{array}{l}\text { At the end of sentence need to add } \\
\text { full stop. }\end{array}$ \\
\hline $\mathrm{W}$ & $\begin{array}{l}\text { It is a strange looking animal } \\
\text { which has thick legs, huge sides } \\
\text { and backs, large hanging ears, a } \\
\text { small tail, little pair of eyes, } \\
\text { long white tusks and above all, } \\
\text { elephant has a long nose called } \\
\text { the trunk. }\end{array}$ & $\begin{array}{l}\text { After tusks and before and need to } \\
\text { add a comma. }\end{array}$ \\
\hline $\mathrm{Z}$ & $\begin{array}{l}\text { During the week of tabuik. } \\
\text { many activities are held } \\
\text { including kite race and ot her. } \\
\text { tradisional activities. }\end{array}$ & $\begin{array}{l}\text { The full stop after tabuik need to } \\
\text { replace with comma, also the full } \\
\text { stop after her need to replace with } \\
\text { comma. }\end{array}$ \\
\hline
\end{tabular}

\section{Text organization error}

Text oranization error is error that occur when the construction of the text does not follow the rules in the generic structure of the text type. From the analysis, the writer found that from 27 samples, there is 1 student who make error in the construction of text organization.

Table 4.1.11 Text organization error

\begin{tabular}{lll}
\hline $\begin{array}{l}\text { Students } \\
\text { Name }\end{array}$ & Initial & Description \\
\hline Y & The type of the text. & The text organization of the text does not \\
& seem to be a report text. It is more likely \\
& a news item. \\
\hline Total students' errors in text organization $=$ & 1 Student \\
\hline
\end{tabular}

From the data collection above, the writer finds out that most students do errrors in the word form. 11 students do errors in their construction in word form 
in writing report text and then followed by the errors in word choice. 10 students do errors in their word choice. Next, followed by error in punctuation. 9 students do error in the punctuation.

After analyzing the data, in this part, the writer describe the possible cause of error that faced by the students in writing the report text. As there are 11 instruments of the writing error in report text, the writer found out that the possible cause of error as follows:

1. Subject-verb agreement error, The possible cause of students to make error in the subject-verb agreement construction is students do not know about how to put suitable verb after a subject.

2. Verb tense error, The possible cause of students to make error in the verb tense is students do not know what tense used in a text. More causes is because the students do not understand about tenses at all.

3. Verb form error, The possible cause of students to make error in the verb form is students do not know about what form of verb suit in a sentence. It refers to the participle, past, and also past participle.

4. Singular/plural ending error, The possible cause of students to make error in the singular/plural ending construction is students do not know whether the noun they used is singular or plural. They sometimes confused in deciding if the noun is in singular or plural form.

5. Word form error, The possible cause of students to make error in the word form construction is students do not know about how to write the word based on the standard of English language.

6. Word choice error, The possible cause of students to make error in the word choice is students do not know about what word fit a sentence in term of context. Some words have similar meaning but not used in every same situation.

7. Article error, The possible cause of students to make error in the article is students do not know about the use of each article in English. There are 3 kinds of article with their own rule in the use. Each of them gives different meaning if the students do not know how to use it correctly. 
8. Preposition error, The possible cause of students to make error in the preposition is students do not know about the use of each preposition in English. There are 3 kinds of preposition including in, at, and on with their own rule in the use. Each of them gives different meaning if the students do not know how to use it.

9. Phrasal verb error, The possible cause of students to make error in the phrasal verb construction is pretty complicated. The reasons are commonly appear in the construction of the verb after a helping verb. This is because the students have low knowledge about the construction of sentence based on the tenses used in the text.

10. Punctuation error, The possible cause of students to make error in the punctuation is students do not know about the use of the punctuation itself. As when to use a comma and even the importance of a full stop at the end of a sentence.

11. Text organization error, The possible cause of students to make error in the text organization construction is students do not know about the generic structure of the text that they write. Another reason also found that some students have less knowledge about the types of text in English.

\section{DISCUSSION}

The discussion of this research covered the main result of the study. It is found that most students did error in word form that can be claimed as the most troublesome instrument for the students in writing the report text. Secondly followed by word choice error that possibly caused by students that had less vocabulary. Thirdly followed by punctuation error that takes serious part in the writing. Possibly happened by students who did not know about the use of correct punctuation in specific sentence.

These three instruments are the parts that should be considered the most in teaching writing. It is proven from this research that the students' main problems are really crucial in writing. Teachers need to put serious attention in these instruments.

\section{CONCLUSION}


After analyzing the students' writing error in report text, the writer made several points of conclusion. There are:

1. Most students did errors in word form that consisted of 14 students and then followed by word choice errors that consist of 10 students, and also in punctuation errors that consist of 9 students, which means that the students were difficult in constructing the word form, word choice, and also punctuation in writing report text.

2. This research determined that the possible causes of error were:

a. The students had less vocabulary so their writing showed that their construction in word form did so many errors. It was because the students did not know how to write it correctly. It was also could be proven from the word choice errors that the students did not have enough vocabulary to decide what vocabulary would fit a sentence based on the context of the sentence.

b. The students did not know how to use punctuation in a correct manner.

c. The carelessness also gave great amounts of errors in writing the report text.

\section{SUGGESTION}

After analyzing the students' writing errors in report text, the writer had several suggestions for the improvement of the students' writing especially in writing report text and also for the future research in writing report text. They were:

1. In teaching writing especially in writing report text, the teacher should put a serious intention in the part of word choice, word form, and also punctuation since these instruments are the most troublesome parts in this research of the students' writing error.

2. The teacher need to explain about word form, word choice, and also punctuation deeply before jump into the writing of the text. 


\section{REFERENCES}

Arikunto, S. 2006. Dasar-dasar Evaluasi Penilitian Pendidikan Jakarta: Bumi Aksara.

Arikunto, S. 2006. Prosedur Penelitian, Suatu Pendekatan Praktek. Jakarta: Rineka Cipta.

Belmont and Sharkey. 2011. The Easy Writer: Formal Writing for Academic Purposes, $3^{\text {rd }}$ Edition. Australia.

Brown, D.H. 1980. Principles of Language Learning and Teaching. United States of America.

Brucem, I. 2008. Academic Writing and Genre. New York.

Chandler, D. 2000. An Introduction to Genre Theory. Australia.

Devitt, A. 2004. Writing Genres. Southern Illinois University.

Elder, S. 2009. ILO school to work transition survey: A methodological guide. International Labour Organization.

Handcock and Gile. August 2011. On the Concept of SnowballSampling.England.

Khansir, A.A. May 2012. Error Analysis and Second Language Acquisition. Finland.

Knapp and Watkins. 2005. Genre, Text, Grammar. Australia: University of New SouthWales.

Llach, A.P.M. 2011. Lexical Errors and Accuracy in Foreign Language Writing. Ireland: Trinity College.

Mertens, N. 2010. Writing: Processes, Tools, and Techniques. New York: Nova Science Publisher.

Rizka, H and Hidayati, N.N. 2015. Mega Bank of Grammar. Yogyakarta: Pustaka Baru Press.

Sugiyono. 2012. Metode Penelitian Administrasi. Bandung: Alfabeta.

Suprapto. 2013. Metodologi Pendidikan: Ilmu pendidikan dan Ilmu-Ilmu Pengetahuan Sosial. Jakarta: PT. Buku Seru. 